\title{
CZY PANDEMIA COVID-19 CZASOWO ZATRZYMAŁA ZJAWISKO OVERTOURISM?
}

\author{
Pinaz Tiwaria (D), Nimit Chowdhary ${ }^{\mathrm{b}}$ \\ ${ }^{a}$ Uniwersytet Centralny Jamia Millia Islamia, New Delhi (Indie), Wydział Turystyki i Hotelarstwa; \\ http://orcid.org/0000-0003-0631-3377; e-mail: tiwaipinaz@yahoo.com \\ ${ }^{\text {b }}$ Uniwersytet Centralny Jamia Millia Islamia, New Delhi (Indie), Wydział Turystyki i Hotelarstwa; \\ https://orcid.org/0000-0002-7335-2379; e-mail: nchowdhary@jmi.ac.in
}

\begin{abstract}
ABSTRAKT
Pandemia COVID-19 spowodowała radykalne zmiany w codziennym życiu ludzi oraz funkcjonowaniu gospodarek. Uważa się, iż zmiany te mają charakter ewolucyjny i zapoczątkują nową fazę transformacji, jednak praktyki stosowane obecnie zarówno przez osoby prywatne, jak i przez firmy mogą zostać zaniechane, gdy kryzys dobiegnie końca. W kontekście podróżowania powrót do nieodpowiedzialnych zachowań doprowadziłby do ponownego pojawienia się niechęci do turystyki. Celem niniejszej notatki jest rozważenie, czy pandemia COVID-19 jedynie czasowo rozwiązała istniejący wcześniej problem nadmiernej turystyki (overtourism) i związanego z nią braku stosowania zrównoważonych praktyk. Mimo iż ograniczenia w podróżowaniu wprowadzane przez różne państwa ze względu na rozprzestrzenianie się koronawirusa spowodowały wystąpienie zjawiska zamrożenia turystyki (zero tourism), w większości krajów świata działania w sektorze turystycznym zostały już wznowione. Autorzy niniejszej notatki, prezentując ramy koncepcyjne, podkreślają że jeśli branża będzie nadal funkcjonować na takich samych zasadach jak przed pojawieniem się koronawirusa, problem nadmiernej turystyki wróci po zakończeniu się pandemii. Dlatego też, aby nie dopuścić do takiego rozwoju sytuacji, autorzy sugerują położenie nacisku na turystykę jakościowa, wpajanie podróżującym odpowiedzialnych zachowań oraz wykorzystywanie zdobyczy technologicznych.
\end{abstract}

\section{SŁOWA KLUCZOWE}

COVID-19, overtourism, zero tourism, odpowiedzialne zachowanie, turystyka zrównoważona

\section{INFORMACJE O ARTYKULE}

Przyjęto:

29 października $2020 \mathrm{r}$.

Zaakceptowano:

17 maja $2021 \mathrm{r}$.

Opublikowano:

25 czerwca $2021 \mathrm{r}$.

\section{WSTĘP}

Na początku 2020 r. pandemia COVID-19 niespodziewanie spowodowała zahamowanie działań w sferze społecznej i gospodarczej na skalę globalną. W turystyce jako jednym z najistotniejszych sektorów społeczno-gospodarczych następstwa nałożenia ograniczeń w przemieszczaniu się oraz w transporcie są bardzo odczuwalne. Obostrzenia te gwałtownie doprowadziły do zamrożenia turystyki ${ }^{1}$, co z kolei przyczyniło się do zamykania firm, bezrobocia oraz bankructw w branży
(World Travel and Tourism Council, 2020). W czasie gdy świat walczy z pandemią i jej niepożądanymi skut-kami, w wielu krajach przybiera na sile dyskurs na temat "nowej normalności”.

$\mathrm{Z}$ jednej strony w przeprowadzonych niedawno badaniach dotyczących tej branży pandemia jest traktowana jako siła transformacyjna $w$ turystyce i hotelarstwie (Brouder, 2020). Mówi się nawet, iż pandemia może się okazać nie tylko niszczycielką, lecz również nauczycielką - wprawdzie spowodowała ona katastrofę, ale przyczynia się także do wytworzenia nowych 
nawyków (Tomes, 2010). Z drugiej strony zakaz przemieszczania się, nagłe zahamowanie działalności turystycznej oraz powszechne wdrożenie zasad dystansu społecznego wywołały w ludziach raczej pragnienie powrotu do normalności niż akceptację możliwej „nowej normalności” (Brouder i in., 2020). Jednakże powrót do rzeczywistości sprzed pandemii oznaczałby prawdopodobnie wznowienie stosowania niezrównoważonych praktyk. Branża turystyczna jest często krytykowana za skupianie się wyłącznie na liczbie turystów bądź na wzroście ilościowym, a nie jakościowym (Benner, 2020; Koens, Postma, 2018), co z kolei przyczyniło się do zaistnienia w znanych miejscowościach turystycznych takich zjawisk, jak: nadmierna turystyka (overtourism), turystofobia (tourismphobia), ruchy antyturystyczne itp. (Zerva, Palou, Blasco, Donaire, 2019). Co więcej, kluczową przeszkodą na drodze do zrównoważonego rozwoju turystyki jest krótkoterminowa wizja korzyści ekonomicznych. Kwestie te odzwierciedlają „nagromadzenie przeciwności" wywołanych przez turystykę. Pomimo złożoności koncepcji nadmiernej turystyki jest jasne, że problem ten występuje powszechnie w niektórych popularnych celach podróży (Bertocchi, Camatti, Giove, van der Borg, 2020; Hughes, 2018). Niemniej jednak po wybuchu pandemii COVID-19 udało się go pozbyć, przynajmniej tymczasowo.

Autorzy niniejszej notatki naukowej podkreślaja, iż pandemia spowodowała wyłącznie chwilowe zahamowanie uprzednio występujących zjawisk nadmiernej turystyki i przepełnienia regionów docelowych. Praca ma charakter perspektywiczny. Skupiono się w niej na nieprzewidywalności turystyki, jednocześnie badając problem ponownego pojawienia się nadmiernej turystyki po wynalezieniu szczepionki i udostępnieniu jej na skalę globalną. Najwyraźniej kryzys związany z COVID-19 spowodował wciśnięcie na Ziemi przycisku „reset”. Przyroda odżyła, wody się oczyściły (co widać choćby na przykładzie Wenecji), a środowisko naturalne jako całość stało się czystsze niż przedtem (Muhammad, Long, Salman, 2020). Bez wątpienia pandemia jest ukrytym błogosławieństwem, dzięki któremu ludzie mogą zastanowić się nad swoim zachowaniem.

\section{OVERTOURISM - PODSUMOWANIE OKRESU PRZED PANDEMIĄ COVID-19}

W ciągu ostatniej dekady niekontrolowany rozwój branży turystycznej przyciągał coraz więcej inwestorów (World Tourism Organization, 2004). W 2018 r. mogliśmy zaobserwować przepływ ok. 1,4 mld turystów międzynarodowych na całym świecie, a tym samym został wówczas osiągnięty cel wyznaczony na 2020 r. Ten bezprecedensowy wzrost w sektorze przyniósł nie tylko korzyści gospodarcze, lecz również negatywne skutki dla lokalnych społeczności (Murzyn-Kupisz, Holuj, 2020; Perkumienè, Pranskūnienè, 2019), środowiska (Benner, 2019; Weber i in., 2017), a także samych miejscowości wypoczynkowych. W kilku bardziej znanych, jak: Wenecja, Barcelona, Maya Bay w Tajlandii, Dubrownik, Amsterdam i Machu Picchu, zaczęto bardzo odczuwać niespotykany dotąd rozwój turystyki i wzrost liczby turystów.

W 2018 r. overtourism stał się jednym z kontrowersyjnych tematów omawianych zarówno przez media, jak i przez naukowców (Goodwin, 2017; Muler Gonzalez, Coromina, Galí, 2018; Peeters i in., 2018), a w konsekwencji termin ten został uznany za słowo roku. Kluczowym problemem jest nagromadzenie zbyt wielu turystów w tym samym miejscu i czasie (Kuščer, Mihalič, 2019; Perkumienė, Pranskūnienè, 2019). Głównymi przyczynami powstawania tego zjawiska są: wzrost dochodu rozporządzalnego, chęć zwiedzania świata, powstawanie nowych możliwości w zakresie zakwaterowania oraz lepsze niż wcześniej połączenia transportowe, które wpłynęły na upowszechnienie się turystyki (Tiwari, Kainthola, Chowdhary, 2020a).

Niemniej jednak overtourism nie jest zjawiskiem nowym (Wall, 2020), gdyż jego negatywne skutki omawiano pośrednio, o ile nie bezpośrednio, już w latach 60. XX w. Doxey (1975), Butler (1980) oraz kilku innych autorów badało utrudnienia, z jakimi społeczności regionów recepcyjnych muszą się mierzyć ze względu na nadmierną liczbę turystów. Niedawno Butler (2019) zbadał ponownie ograniczenie przepustowości, uznawane za główną przyczynę nadmiernej turystyki. W opisie badania przeprowadzonego w 1976 r. Pizam wskazał, iż znacząca liczba turystów w danym miejscu wypoczynku prowadzi do niezadowolenia lokalnej społeczności, co znajduje odzwierciedlenie w niezdrowym podejściu do gości (Pizam, 1978). Na ten fenomen zwrócił uwagę także Goodwin (2017, s. 1), który w stworzonej przez siebie definicji nadmiernej turystyki napisał, że występuje ona $\mathrm{w}$ „miejscach docelowych, gdzie gospodarze bądź goście, lokalni mieszkańcy bądź odwiedzający czują iż turystów jest zbyt wielu, a jakość życia na danym obszarze bądź jakość doświadczenia spadły do nieakceptowalnego poziomu". Prościej rzecz ujmując, o zjawisku overtourism mówimy wtedy, gdy turystów jest więcej, niż destynacja może przyjąć. Nadmierna turystyka, uważana za antytezę odpowiedzialnej turystyki (Goodwin, 2017), jest dość rozmytą koncepcją (Bertocchi, Camatti, Giove, van der Borg, 2020), ponieważ obejmuje spostrzeżenia dotyczące turystów (Milano, Novelli, Cheer, 2019) i mieszkańców (Kuščer, Mihalič, 2019). Tym 
samym nietrudno sobie uświadomić, iż pewne zjawiska mają wpływ na popularne cele podróży na całym świecie (Benner, 2020).

\section{CZY PANDEMIA COVID-19 SPOWODOWAŁA TYMCZASOWE ZAHAMOWANIE ZJAWISKA OVERTOURISM?}

Goodwin (2017) przestrzegał, iż w niektórych regionach docelowych można się spodziewać wystąpienia zjawiska overtourism, jeśli turystyka będzie się rozwijać w sposób niekontrolowany w dotychczasowym tempie. Świat jednak jest tak nieprzewidywalnie zmienny, iż w 2020 r. problem nadmiernej turystyki tymczasowo zniknął. W wyniku wybuchu pandemii COVID-19 nastąiło przejście od turystyki nadmiernej do jej zamrożenia (zero tourism).

Najbardziej oczywistą tendencją prognozowaną przez badaczy, jest zmiana poglądów turystów oraz mieszkańców miejscowości wypoczynkowych. Jednak ze względu na perspektywę ponownego otwarcia granic oraz złagodzenia obostrzeń związanych z podróżowaniem branża turystyczna przygotowuje się do podjęcia kroków, by wyjść naprzeciw oczekiwaniom turystów. Wobec tego autorzy niniejszej pracy przewiduja, że w okresie po pandemii COVID-19 zjawisko overtourism może pojawić się ponownie (rys. 1). Powrót nadmiernej turystyki został zapoczątkowany przez wynalezienie szczepionki i stopniowe zwiększanie jej dostępności, po których nastąpi „kryzys pamięci” związany ze znoszeniem ograniczeń w podróżowaniu oraz $\mathrm{z}$ uznawaniem go za mniej ryzykowne. Zjawisko to wpłynie na organizacje turystyczne i regiony docelowe, w których zostanie wdrożona strategia ekstensywnego wzrostu, by wyrównać straty poniesione w wyniku pandemii. Finalnie zwiększenie się popytu doprowadzi do rozpowszechnienia nieodpowiednich i nieodpowiedzialnych praktyk, od których uwagę będzie odciągał

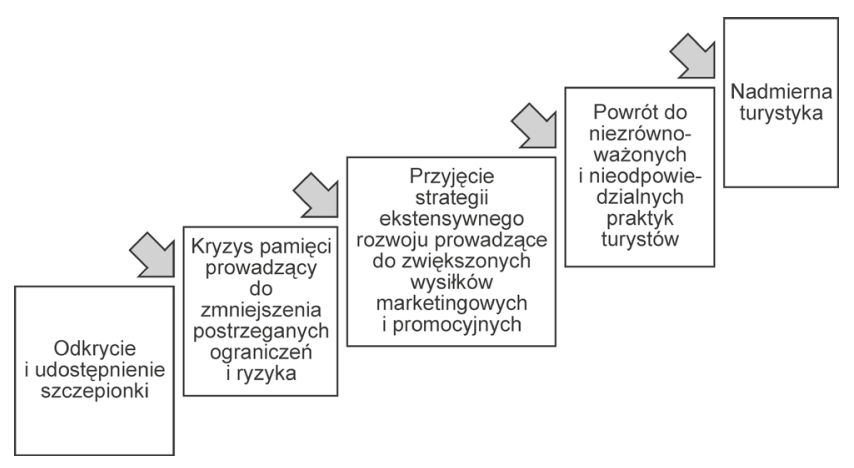

Rysunek 1. Ramy koncepcyjne

dla ponownego pojawienia się zjawiska nadmiernej turystyki Źródło: opracowanie własne autorów wzrost liczby osób przybywających w dane miejsce. Wszystko to razem doprowadzi do ponownego pojawienia się zjawiska nadmiernej turystyki w okresie po pandemii COVID-19.

W kontekście kryzysu w branży Farmaki (2020) omawia pokryzysowe zachowania turystów, które odzwierciedlają ich „zapominalstwo", czego dowodem są wzorce zachowań związanych ze wznowieniem podróżowania. Autor podkreśla, iż podróżujący mają skłonność do zapominania o kryzysie i po tym, jak zostali nim pośrednio dotknięci, zazwyczaj po dłuższej przerwie i tak ponownie wyruszają na wyprawy. Ich plany ulegają wzmocnieniu ze względu na zmiany w pragnieniach i motywacjach do podróżowania, takie jak odwiedzanie rodziny i znajomych (Zenker, Kock, 2020) czy pojawienie się w obecnej sytuacji tzw. bańki turystycznej (Lapointe, 2020).

Organizacje turystyczne przyjmą strategię ekstensywnego wzrostu, aby ożywić branżę i zaspokoić kształtujący się ponownie popyt, choć oczywiście będzie on mniejszy niż uprzednio. Strategie rozwoju po pandemii COVID-19 są czynnie opracowywane przez wszystkie podmioty turystyczne, tj. zarówno przez organizacje typu destination management (DMO), jak i przez komercyjne przedsiębiorstwa turystyczne, by przyciągnąć większą liczbę turystów i ożywić branżę.

Seraphin i Ivanov (2020) przedstawili strategię ekstensywnego rozwoju, ukierunkowaną na zwiększenie liczby przybywających osób. Plan ten wymaga zwiększenia wysiłków marketingowych regionu docelowego. W celu odrobienia strat poniesionych w czasie obecnego globalnego kryzysu zdrowotnego, w sektorze turystycznym konieczne będzie podejmowanie wzmożonej działalności marketingowej i reklamowej, dzięki czemu powrót na rynek stanie się możliwy, gdy potencjalni klienci uznaja, że ryzyko zmalało.

Kilka organizacji turystycznych rozpoczęło już wydawanie voucherów na przyszłe podróże, a w niedługim czasie dostępne staną się także promocje cenowe. Lufthansa - narodowy niemiecki przewoźnik - przewiduje, że setki należących do niej samolotów będą uziemione do 2022 r., w fazie wychodzenia z kryzysu zaś popyt może przewyższyć podaż (Fanthorpe, 2020). Niedawny przypadek ",turystyki rewanżu” (revenge travel), promowanej przez rząd chiński (Kuo, 2020), może posłużyć jako odpowiedni przykład ilustrujący opisany model koncepcyjny.

Choć sektorowi turystycznemu daleko do doskonałości ze względu na nagminne zanieczyszczanie otoczenia, dokonywanie zniszczeń oraz generowanie kosztów ekonomicznych obciążających społeczność obszaru recepcji, należy zauważyć, że przynosi on również przyjemność i doświadczenia transformacyjne turystom oraz korzyści gospodarcze społeczeństwu (Butler, 2020). Wskutek tego warunkiem koniecznym 
zrównoważonej turystyki jest wyważone podejście. Zakłada ono podjęcie zsynchronizowanych działań w kierunku uznania, że turyści mają prawo do podróżowania, a mieszkańcy - do satysfakcjonującej jakości życia. Realizacja przedsięwzięć mających na celu zmianę turystyki po pandemii COVID-19 w usługę luksusową powstrzymałaby turystów przed nadmiernym korzystaniem z niej. Natomiast wprowadzanie zbyt dużych obniżek cen i organizowanie agresywnych kampanii reklamowych prawdopodobnie spowoduje nadmierny popyt. Zwiększenie liczby turystów w danym regionie docelowym może zaś stać się przyczyną ponownego wystąpienia zjawiska overtourism oraz znacząco obniżyć jakość życia mieszkających tam ludzi.

\section{DROGA}

\section{KU TRWAŁEMU ROZWIĄZANIU PROBLEMU NADMIERNEJ TURYSTYKI}

Każde zjawisko może mieć zarówno pozytywne, jak i negatywne skutki, jeśli nie będzie obserwowane i skutecznie kontrolowane. Monitorowanie poprzez wdrażanie planów może pomóc w opracowywaniu zasad i strategii odpowiednich dla danego miejsca docelowego. Oczywiście problemy związane nie tylko z nadmierna, ale również z zerową turystyką są niepożądane i wiążą się z niekorzystnym wpływem na lokalną społeczność oraz przemysł. Bez wątpienia niekontrolowana liczba turystów, podobnie jak ich zupełny brak, nie oznacza dla regionu pobytu perspektyw zrównoważonego rozwoju (Seraphin, Ivanov, 2020).

Konieczne jest zagwarantowanie, iż ludzie na całym świecie nie wrócą do wcześniejszych toksycznych praktyk i wezmą pod uwagę powtarzające się ostrzeżenia, które branża turystyczna otrzymywała ze względu na brak równowagi. Z kolei „zanik wzrostu” w turystyce doprowadziłby do zubożenia milionów osób, których utrzymanie zależy od funkcjonowania branży. Dlatego też sytuacja wymaga wyważonego podejścia, które pomoże zapobiec występowaniu takich zjawisk, jak nadmierna i niesatysfakcjonująca skala turystyki.

Seraphin i Ivanov (2020) uważają iż skupienie się na intensywnym wzroście powiązanym z zarządzaniem przychodami, podobnie jak kilka innych rozwiązań zaproponowanych przez badaczy i decydentów, mogłoby przynieść zyski i pomóc uniknąć problemu zarówno nadmiernej, jak i niedostatecznej turystyki. Do tych propozycji należą m.in.: włączenie do kompozycji marketingowej strategii obniżających popyt (Tiwari, Kainthola, Chowdhary, 2020a), wdrożenie rozwiązań technologicznych pomagających w radzeniu sobie z problemem nadmiernej turystyki (Hospers, 2019) oraz edukacja turystyczna, dzięki której miejsca docelowe stałyby się „inteligentne” i „zrównoważone” (Tiwari, Kainthola, Chowdhary, 2020b). Jednakże strategie te w większości wiążą się z wprowadzaniem ograniczeń oraz $\mathrm{z}$ różnicowaniem i wzrostem cen produktów, co rodzi pytania o prawo turystów do podróżowania. Ponadto pogląd, iż osoby, które wydadzą w danym miejscu więcej pieniędzy, będą zachowywać się bardziej odpowiedzialnie, jest mitem.

W związku z tym autorzy niniejszej notatki naukowej sugeruja, że w zwalczaniu negatywnych skutków turystyki w okresie po pandemii COVID-19 pomocne byłyby następujące działania:

- położenie nacisku na turystykę jakościowa,

- wykorzystywanie rozwiązań technologicznych w procesie konsumpcji,

- koordynacja poszczególnych komponentów branży turystycznej w danym miejscu docelowym,

- repozycjonowanie istniejących strategii marketingowych,

- włączanie innowacyjnych produktów, poprzedzone ponowną analizą trendów kształtujących się na rynku,

- respektowanie zrównoważonego rozwoju i odpowiedzialności biznesu jako moralnego nakazu (rys. 2).

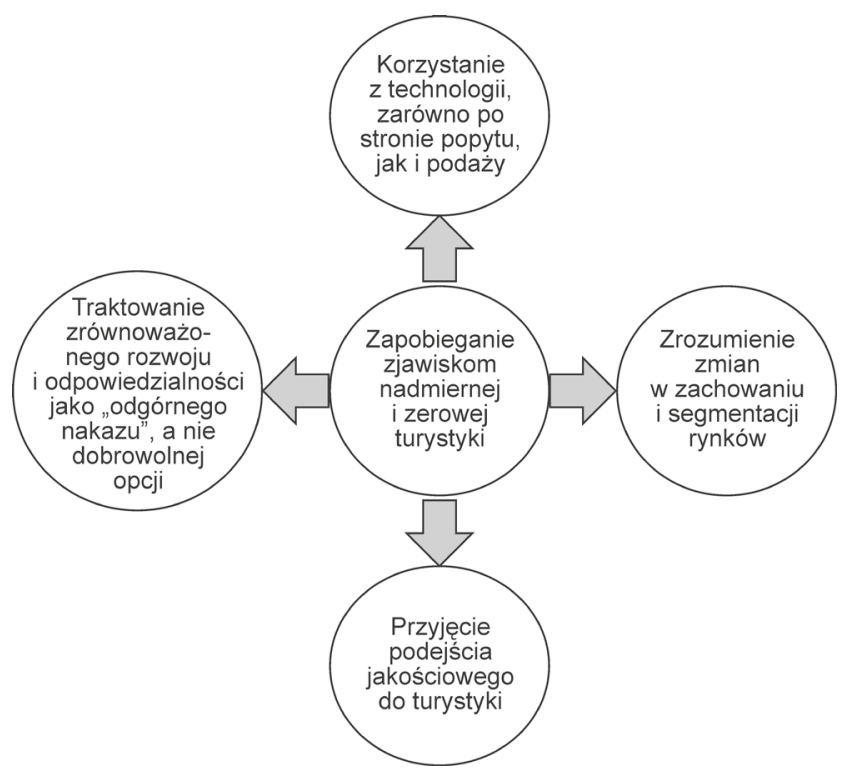

Rysunek 2. Zapobieganie nadmiernej i zerowej turystyce w okresie po pandemii COVID-19

Źródło: opracowanie własne autorów

Pandemia COVID-19 zmusza ludzkość do zastanowienia się nad brakiem równowagi w podróżowaniu w czasach przed rozprzestrzenieniem się koronawirusa. Niemniej jednak najbardziej palącą kwestią jest, by w branży turystycznej nie powrócono do niedbałego postępowania, które dało początek nieodpowiednim, niewyważonym praktykom. 


\section{PRZYPIS}

${ }^{1}$ Użyty w anglojęzycznej wersji artykułu termin zero tourism $\mathrm{w}$ tekście polskim został przetłumaczony jako turystyka zerowa lub zamrożenie turystyki. Pojęcia te są tu traktowane jako synonimy.

\section{BIBLIOGRAFIA}

Benner, M. (2019). From overtourism to sustainability: A research agenda for qualitative tourism development in the Adriatic. Zeitschrift für Wirtschaftsgeographie = German Journal of Economic Geography, 2 (64), 74-87.

Benner, M. (2020). The decline of tourist destinations: An evolutionary perspective on overtourism. Sustainability, 12 (9), 3653. https://doi.org/10.3390/su12093653

Bertocchi, D., Camatti, N., Giove, S., van der Borg, J. (2020). Venice and overtourism: Simulating sustainable development scenarios through a tourism carrying capacity model. Sustainability, 12 (2), 512. https://doi.org/10.3390/su12020512

Brouder, P. (2020). Reset redux: Possible evolutionary pathways towards the transformation of tourism in a COVID-19 world. Tourism Geographies, 22 (3), 484-490. https://doi.org/10.1080/1 4616688.2020.1760928

Brouder, P., Teoh, S., Salazar, N.B., Mostafanezhad, M., Pung, J.M., Lapointe, D., Clausen, H.B. (2020). Reflections and discussions: Tourism matters in the new normal post COVID-19. Tourism Geographies, 22 (3), 1-12, 735-746. https://doi.org/10.1080/146 16688.2020.1770325

Butler, R. (2020). From too many to too few: The impact of COVID-19 on overtourism. Pobrane z: https://blog.cabi.org/2020/06/02/ from-too-many-to-too-few-the-impact-of-covid-19-on-overtourism/ (12.09.2020).

Butler, R.W. (1980). The concept of a tourist area cycle of evolution: Implications for management of resources change on a remote island over half a century view project. Canadian Geographer, XXIV (1), 5-12. https://doi.org/10.1111/j.1541-0064.1980. tb00970.x

Butler, R.W. (2019). Tourism carrying capacity research: A perspective article. Tourism Review, 75 (1), 207-211. https://doi. org/10.1108/TR-05-2019-0194

Doxey, G.V. (1975). A causation theory of visitor-resident irritants: Methodology and research inferences. Sixth Annual TTRA Conference.

Fanthorpe, H. (2020). Could Covid-19 be the end of overtourism? Pobrane z: https://www.roughguides.com/article/could-covid-19-be-the-end-of-overtourism/ (13.09.2020).

Farmaki, A. (2020). Memory and forgetfulness in tourism crisis research. Tourism Management, 83, 104210. https://doi. org/10.1016/j.tourman.2020.104210

Goodwin, H. (2017). The challenge of overtourism. Responsible Tourism Partnership Working Paper, 4. Pobrane z: http://haroldgoodwin.info/pubs/RTP'WP4Overtourism01'2017.pdf (12.07.2020).

Hospers, G.J. (2019). Overtourism in European cities: From challenges to coping strategies. CESifo Forum, 20 (3), 20-24.

Hughes, N. (2018). 'Tourists go home': Anti-tourism industry protest in Barcelona. Social Movement Studies, 17 (4), 471-477. https://doi.org/10.1080/14742837.2018.1468244

Koens, K., Postma, A. (2018). Understanding and managing visitor pressure in urban tourism. Pobrane z: https://www.celth.
nl/sites/default/files/2018-09/Voorkomen\%20van\%20bezoekersdruk\%20in\%20Europese\%20steden.pdf (17.03.2020).

Kuo, L. (2020). China promotes 'revenge travel' to boost economy after Covid lockdowns. Pobrane z: https://www.theguardian. com/world/2020/oct/01/china-promotes-revenge-travel-boost-economy-coronavirus-golden-week (2.10.2020).

Kuščer, K., Mihalič, T. (2019). Residents' attitudes towards overtourism from the perspective of tourism impacts and cooperation - the case of Ljubljana. Sustainability, 11 (6), 1823. https:// doi.org/10.3390/su11061823

Lapointe, D. (2020). Reconnecting tourism after COVID-19: The paradox of alterity in tourism areas. Tourism Geographies, 22 (3), 633-638. https://doi.org/10.1080/14616688.2020.17 62115

Milano, C., Novelli, M., Cheer, J.M. (2019). Overtourism and tourismphobia: A journey through four decades of tourism development, planning and local concerns. Tourism Planning and Development, 16 (4), 353-357. https://doi.org/10.1080/2156 8316.2019.1599604

Muhammad, S., Long, X., Salman, M. (2020). COVID-19 pandemic and environmental pollution: A blessing in disguise? Science of the Total Environment, 728, 138820. https://doi.org/10.1016/j. scitotenv.2020.138820

Muler Gonzalez, V., Coromina, L., Galí, N. (2018). Overtourism: Residents' perceptions of tourism impact as an indicator of resident social carrying capacity - case study of a Spanish heritage town. Tourism Review, 73 (3), 277-296. https://doi. org/10.1108/TR-08-2017-0138

Murzyn-Kupisz, M., Holuj, D. (2020). Museums and coping with overtourism. Sustainability (Switzerland), 12 (5). https:// doi.org/10.3390/su12052054

Peeters, P., Gössling, S., Klijs, J., Milano, C., Novelli, M., Dijkmans, C., Eijgelaar, E., Hartman, S., Heslinga, J., Isaac, R., Mitas, O., Moretti, S., Nawijn, J., Papp, B., Postma, A. (2018). Research for TRAN Committee - Overtourism: Impact and possible policy responses. European Parliament, Policy Department for Structural and Cohesion Policies, Brussels. Pobrane z: http://www.europarl.europa.eu/thinktank/en/document.html?reference=IPOL_ STU(2018)629184 (8.07.2020).

Perkumienè, D., Pranskūnienė, R. (2019). Overtourism: Between the right to travel and residents' rights. Sustainability, 11 (7), 1-17. https://doi.org/10.3390/su11072138

Pizam, A. (1978). Tourism's impacts: The social costs to the destination community as perceived by its residents. Journal of Travel Research, 16 (4), 8-12. https://doi. org/10.1177/004728757801600402

Seraphin, H., Ivanov, S. (2020). Overtourism: A revenue management perspective. Journal of Revenue and Pricing Management, 19 (3), 146-150. https://doi.org/10.1057/s41272-020-00241-7

Tiwari, P., Kainthola, S., Chowdhary, N.R. (2020a). Demarketing: A marketing framework for overtourism. W: C. Ribeiro de Almeida, A. Quintano, M. Simancas, R. Huete, Z. Breda (red.), Handbook of research on the impacts, challenges, and policy responses to overtourism (s. 94-114). Londyn: IGI Global. https:// doi.org/10.4018/978-1-7998-2224-0.ch006

Tiwari, P., Kainthola, S., Chowdhary, N.R. (2020b). Empowering tourism education as a destination management tool. W: H. Seraphin, A. Yallop (red.), Overtourism and tourism education (s. 63-80). London: Routledge.

Tomes, N. (2010). "Destroyer and teacher": Managing the masses during the 1918-1919 influenza pandemic. Public Health Reports, 125 (3), 48-62. https://doi.org/10.1177/00333549101250s308

Wall, G. (2020). From carrying capacity to overtourism: A perspective article. Tourism Review, 75 (1), 212-215. https://doi. org/10.1108/TR-08-2019-0356 
Weber, F., Stettler, J., Priskin, J., Rosenberg-Taufer, B., Ponnapureddy, S., Fux, S., Camp, M.A., Barth, M., Klemmer, L.,Gross, S. (2017). Tourism destinations under pressure. WorkingPaper. Lucerne University of Applied Sciences and Arts, Luzern. Pobrane z: https:// static1.squarespace.com/static/56dacbc6d210b821510cf939/t/590 9cb282e69cf1c85253749/1493814076440/WTFL_study12017_full1version.pdf (12.07.2020).

World Tourism Organization (2004). Indicators of sustainable development for tourism destinations. W: Tourism's potential as a sustainable development strategy. Proceedings from the 2004 WTO tourism policy forum at the George Washington University, Washington, DC, USA: WTO.
World Travel and Tourism Council (2020). Leading global protocols for the new normal. (May). Pobrane z: https://wttc. org/COVID-19/Safe-Travels-Global-Protocols-Stamp (12.07.2020). https://doi.org/10.1017/CBO9781107415324.004.

Zenker, S., Kock, F. (2020). The coronavirus pandemic - a critical discussion of a tourism research agenda. Tourism Management, 81, 104164. https://doi.org/10.1016/j.tourman.2020.104164

Zerva, K., Palou, S., Blasco, D., Donaire, J.A.B. (2019). Tourismphilia versus tourism-phobia: Rresidents and destination management organization's publicly expressed tourism perceptions in Barcelona. Tourism Geographies, 21 (2), 306-329. https://doi.org/10.1080/14616688.2018.1522510 